\title{
The Development of Augmented-Reality Based Guided Inquiry Teaching Material of Life Organization System
}

\author{
Linda Suci Triliana $^{a}$, Munzil ${ }^{b, *}$, Sugiyanto ${ }^{c}$ \\ a,b,c Uiversitas Negeri Malang, Semarang Street, Number 5, \\ Malang, East Java, Indonesia \\ *Corresponding author's e-mail: munzil.fmipa@um.ac.id
}

\begin{abstract}
The purposes of this research and development is to produce feasible and valid teaching materials utilizing augmented reality-assisted guided inquiry learning model in the activity of identifying life organizational system for 7th grade students of Junior High School/Islamic Junior High School, as teaching material in Covid-19 Pandemic era. This research used Lee and Owens research and development model, limited to three stages, namely: analysis/assessment, design, and development. The feasibility of the teaching materials were determined from the results of the validation and user assessment. The teaching materials were developed in A6-sized printed books containing Basic Competence 3.6 materials of life organizational system from the cellular level to organismic level. The materials were presented in the forms of illustrations, videos, threedimensional AR animations, and handouts on google drive. Based on the validity result which was conducted by material and media experts, it was discovered that the teaching materials were valid and feasible for learning with the score percentage of more than $81 \%$.
\end{abstract}

\section{Introduction}

Science is a subject to learn the whole universe, both seen and unseen. The purpose is to increase the students' skill based on the needs and competence [1]. Development of technology and science is always growing and adjusting everyday life. The problem with science subject among the secondary school students is the lack of interest from them because of the complicated concepts that exist in it [2]. The diffuculty of students in learning sains that they really depend on teachers who capable of explaining those materials to the students. The delivery is crucial in learning process. Teachers could use varied things to get the students motivated, including using different models, methods, or media effectively and innovatively to make the learning process going fun [3]. 
Indonesian students' science skill is quite low rather than other nations. Data gathered from Program For International Student Assessment (PISA) in 2018 shows Indonesia is on 70 from 78 countries [4]. Indonesia's science skill's result is below international average of 489. The low result of science skill is from the lack of innovation from the teachers in using learning sources and media in the learning process [5]. One of the factors to support independent learning skill is to provide learning source based on the students' needs. Delivery using learning materials is more systematic. The arrangement of teaching materials is tailored to the needs of students which contain deeper knowledge in accordance with the demands of the curriculum that uses simple and concise language, so it can make it easier for student to understand the material independently [6].

The fact is that teachers in schools are still using conventional learning materials. Textbook is learning resources that contain knowledge information that students use in learning. Textbook can be found easily by students, but the completeness of the material is not yet fully able to support student's knowledge in the implementation of learning [7]. Based on the interview, learning materials are from textbooks contained images and texts as basic knowledge so it needs other materials as supporting ones. The use of images and textes in a learning materials make students feel bored, difficult to understand, and less interested to follow the class [8]. One solution to overcome this problem is to use teaching materials that contain media as a visual tool so that students can more easily understand abstract concepts in books.

The media in teaching material is very important with the aim of making it easier for student to understand the material. Therefore, teachers should develop their learning in media to support and improve learning activities [9]. Augmented Reality is a virtual information technology generated from a computer that is combined into a real environment at one time and can be combined with conventional teaching materials to provide a deeper experience and understanding of the material presented [10]. Augmented Reality (AR) technology is capable to visualize abstract concepts in three dimensions and create interesting learning process. Therefore, it makes the students can more easly understand the materials [11]. The use of augmented reality media is suitable for students to visualize, so it will be clear, more realistic, and easier for students to understand the matter [12]. Augmented reality technology is built to provide information virtually so teachers can make proper and active learning for students as 2013 curriculum mandates [13].

In addition to assisting learning media, good teaching material require strategie for managing learning activities. The systematic arrangement of teaching materials uses the syntax of the learning model, so students are able to construct their knowledge independently. Inquiry learning includes series of process activities that emphasize the thinking process of students critically and 
analytically through solving questionable problems to finding conclusions independently [14]. Teachers have crucial role in creating a learning process and to improve quality education. Learning strategy that still centered on teachers creates less critical thinking, ironically it is important to apply the concepts [15]. Therefore, it needs learning strategy to improve students' science processing skill. Guided inquiry learning is whole learning process to find out, investigate systematically and logically to formulate the findings independently [16]. Characteristic of guided inquiry, namely teacher as facilitator of student in carrying out learning activities by providing instruction in the form of questions to guide finding out concepts [17]. Guided inquiry learning is a learning model suggested in 2013 curriculum with teachers as facilitator to guide students to build their knowledge independently. This model is used to improve result, skill, mastery in concept in learning and actively involving students in finding learning concepts [18].

Learning materials need to be developed to keep up current development and to give effective and efficient information which is textbooks contained learning materials and media that accessible to android smartphone users. Media is essential learning material to ease the students in understanding the matter. Therefore, teachers are better developing learning media to support and improve learning [9]. Learning materials that are prepared using guided inquiry learning accesed through google form and contain images, videos, and three dimension animations media to make students understand and construct independent comprehension easier. The other is to use technology in Indonesia during the Covid-19 pandemic era. As Indonesia's Minister of Education issues No.4 2020 letter to conduct learning process in home during Covid-19 pandemic era through online learning that has meaningful experience for students [19]. Based on problems mentioned above, researchers developeed guided inquiry learning model materials in the activity of identifying life organization. The purpose of this development research is to create proper learning materials.

\section{Method}

This research was a development one that refers to Lee, William W., and Diana L. Owens development model is suitable for learning media development including text components, images, animations, and videos. The steps of Lee and Owens model development are assessment/analysis, design, development, implementation, and evaluation (20). Development was carried out limited on the first three phases which are analysis/assessment, design dan development. Analysis phase was divided into two, section, the need analysis and beginning/end analysis. First phase was to do the students' need and obstacle analysis towards subject matter of life organization system materials through interview and observation. Design phase was to design product specification and 
materials development in learning materials. Development phase was to produce embodiment product that suitable the design and to print the book. Lee and Owens' design of development model below as Figure 1.

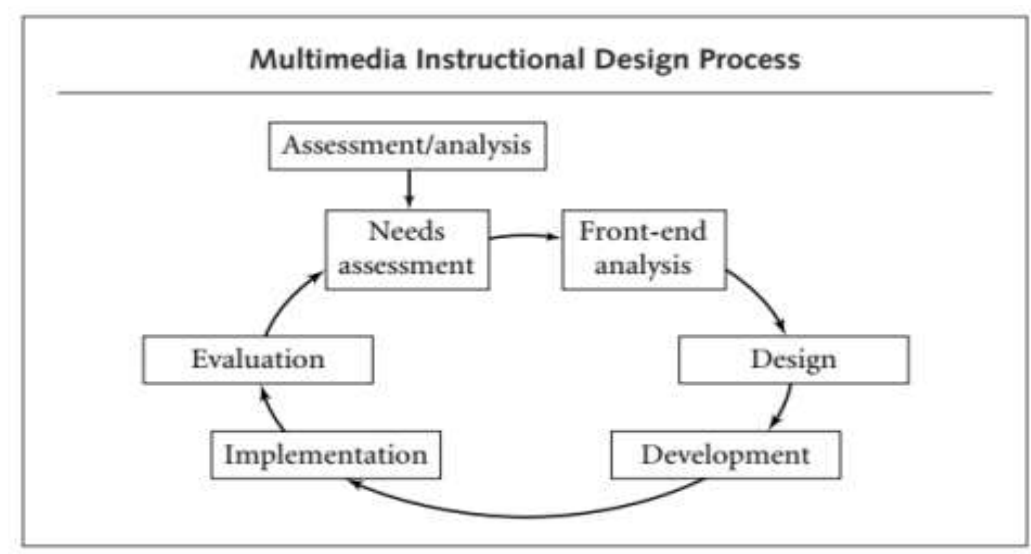

Figure 1. Development Procedure Model

Source: [20]

Product's appropriatness and validity assessment that developed based on validator assessment using validation survey instrument. The subject of the material development test is a minimum five years of experience science teacher. Data collected is qualitative which was consisted of comment and suggestion, and quantitative of score percentage assessment refers to Likert scale and Guttman scale. Quantitative data using Likert scale is Table 1.

Table 1.

Likert Scale

\begin{tabular}{cl}
\hline Score & \\
\hline 4 & Very proper/very good/very agree \\
3 & Proper/good/agree \\
2 & Improper/bad/disagree \\
1 & Very improper/very bad/very disagree \\
\hline
\end{tabular}

Source: [21]

This research also used Guttman scale to find truth of material concept in learning material product. Scoring criteria using this scale as Table 2.

Table 2.

Guttman Scale Scoring Category

\begin{tabular}{cc}
\hline Score & Criteria \\
\hline 1 & Yes/Correct \\
0 & No/Wrong \\
\hline Source: Guttman $(1944)$
\end{tabular}


Data analysis technique to analyse the survey result was descriptive analysis by calculating average score on every component using following formula.

$$
P=\frac{\sum x}{n} \times 100 \%
$$

Informations:

$\mathrm{P} \quad=$ Validity or appropriateness percentage

$\Sigma \mathrm{x} \quad=$ Total of every respondent's answer from every measured component

$n \quad=$ Total respondents

Based on calculated percentage, it could determine product appropriatness criteria. Appropriatness criteria suitable the percentage range is Table 3.

Table 3.

Validity Percentage Scale

\begin{tabular}{cc}
\hline Percentage (\%) & Criteria \\
\hline $0-20$ & Bad/Improper \\
$21-40$ & Less good/Less proper \\
$41-60$ & Rather good/Rather proper \\
$61-80$ & Good/Proper \\
$81-100$ & Very good/Very proper \\
\hline
\end{tabular}

Source: [22]

If the result is $\geq 61 \%$, the product is proper to use as learning media inside or outside the class. If the result is $\leq 60 \%$, the product needs some improvement.

\section{Results}

Learning material is a supporting material book sized A6 $(10,5 \mathrm{~cm} \times 14,8 \mathrm{~cm})$ on Basic Concept 3.6 life organization system material for VII Junior High School/Islamic Junior High School using Augmented reality-assisted technology guided inquiry model. The use of learning material had to be supported by android phones that had barcode scanner and augmented reality apps. Learning materials was composed by supporting and main components. Supporting components were outer and inner cover, preface, table of contents, manual, supporting apps, learning purpose, mind mapping, bibliography and writer's profile page. Main components 
including material presentations were images, videos, three-dimension animations, handout on google drive, inquiry model syntax that accessible on google form.

Validation is carried out by a Science Education Study Program lecturer, Mathematics and Science Faculty, State University of Malang and a Science teacher from Junior High School in Kabupaten Malang, Indonesia. Scoring aspect for quantitative on material validation survey is described in table 4.

Table 4.

Learning Material Validation Analysis Result Percentage

\begin{tabular}{|c|c|c|c|}
\hline No & Scoring Aspects & $\begin{array}{c}\text { Average } \\
\text { Score } \\
\text { Percentage }\end{array}$ & Criteria \\
\hline 1 & Basic competence and learning purpose & $87,5 \%$ & Very approiate \\
\hline 2 & Mind Mapping Presentation & $87,5 \%$ & Very approiate \\
\hline 3 & Grammar & $75 \%$ & Approiate \\
\hline 4 & $\begin{array}{l}\text { Sub material level } 1 \text { : Organization level } \\
\text { concept material }\end{array}$ & $85 \%$ & Very approiate \\
\hline 5 & $\begin{array}{l}\text { Sub material level } 2 \text { : Animals/human and } \\
\text { plants cell material }\end{array}$ & $88,2 \%$ & Very approiate \\
\hline 6 & $\begin{array}{l}\text { Sub material level } 3 \text { : Animals/human and } \\
\text { plants system material }\end{array}$ & $87,5 \%$ & Very approiate \\
\hline 7 & $\begin{array}{l}\text { Sub material level } 4 \text { : Organ, organ system } \\
\text { and Organism material }\end{array}$ & $80,1 \%$ & Approiate \\
\hline & Average & $93.31 \%$ & Very Approiate \\
\hline
\end{tabular}

Average of material validation result percentage was $84,4 \%$ with very approiate criteria. The result of truth of material qualitative data validation is shown on table 5.

Table 5.

Learning Material Qualitative Data Validation

\begin{tabular}{cll}
\hline $\begin{array}{c}\text { Validator } \\
\text { number- }\end{array}$ & \multicolumn{1}{c}{ Comment and Suggestion } & Explanation \\
\hline 1 & $\begin{array}{l}\text { It needs some understandable } \\
\text { words/sentences for students on some } \\
\text { parts. For instance, characteristics, } \\
\text { questions on G-form. }\end{array}$ & $\begin{array}{l}\text { Revision needs to be done by giving } \\
\text { keywords on research questions. }\end{array}$ \\
\hline
\end{tabular}


After material validation is media appropriateness validation. Scoring aspects for quantitative data on validation survey is described in table 6 .

Table 6.

Learning Media Result Analysis Validation Percentage

\begin{tabular}{|c|c|c|c|}
\hline No & Scoring Aspects & $\begin{array}{c}\text { Average Score } \\
\text { Percentage }\end{array}$ & Criteria \\
\hline 1. & Presentation on Cover Design & $83,3 \%$ & Very approiate \\
\hline 2. & Presentation on Content Design & $87,5 \%$ & Very approiate \\
\hline 3. & Animation on Life organization system material & $81,3 \%$ & Very approiate \\
\hline 4. & 3D Marker & $77,5 \%$ & Approiate \\
\hline 5. & $\begin{array}{l}\text { Life organization system material image } \\
\text { presentation }\end{array}$ & $90,6 \%$ & Very approiate \\
\hline
\end{tabular}

Average

$84,0 \%$

Very approiate

Learning media average validation percentage score was $84,0 \%$ with very approiate criteria. Media appropriateness qualitative data validation result is shown in table 7.

Table 7.

Learning Media Qualitative Data Validation

\begin{tabular}{clc}
$\begin{array}{c}\text { Validator } \\
\text { number- }\end{array}$ & Comment and Suggestion & Explanation \\
\hline 1 & $\begin{array}{l}\text { QR code is easy to use. Link's contents } \\
\text { are compatible with learning material }\end{array}$ & - \\
\hline
\end{tabular}

\section{Discussion}

\section{a. Research Result and Development Description}

The learning material is a supporting material book sized A6 $(10,5 \mathrm{~cm} \times 14,8 \mathrm{~cm})$ on BC 3.6 life organization system material for VII SMP/MTs using Augmented reality-assisted technology guided inquiry model. The use of learning material has to be supported by android phones that have barcode scanner and augmented reality apps. Learning materials is composed by supporting and main components. Supporting components are outer and inner cover, preface, table of contents, manual, learning purpose, mind mapping, bibliography and writer's profile page. Main components including four levels or four sub chapter and each level consists of 6 missions that refers to assisted guided inquiry learning model syntax. Material presentations are images, videos, 
three-dimension animations, handout on google drive, inquiry model syntax that accessible on google form therefore it must be online.

Material is divided into four sub-chapters, life level concept, cells, system, organ, system organ, and organism. Each sub-chapter is composed using assisted guided inquiry learning model which are orientation, problem formulation, hypothesis, data collecting, data analyzing, and data conclusion mission. The learning model can facilitate students to construct knowledge independently with teacher's guidance. Inquiry learning model is able to require student to carry out a series of investigations, exploration, search, experiment, and research [23]. Moreover, the learning material use augmented reality technology to make students understand material easier by visualizing abstract concepts such as cell organs on life organization system and also make them interested by three dimension presentations. Augmented Reality is an innovative application that can help various difficulties of student in understanding subjects and an opportunity for online education that can improve learning through student involvement in various learning activities [24]. The use of AR media in learning material is on collecting data mission. Learning material cover presentation and one of the guided inquiry syntax pages in Figure 2.

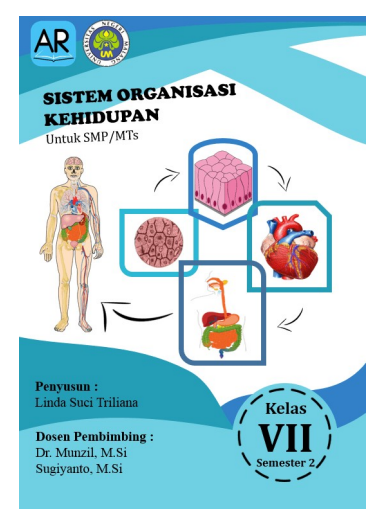

(a)

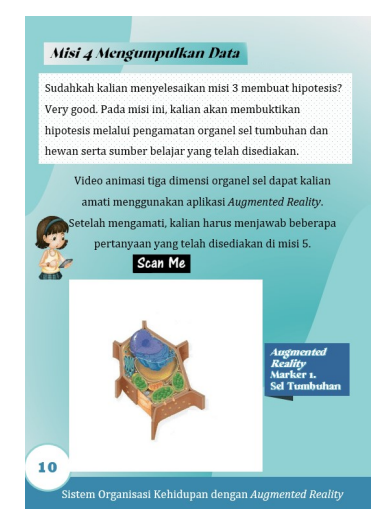

(b)

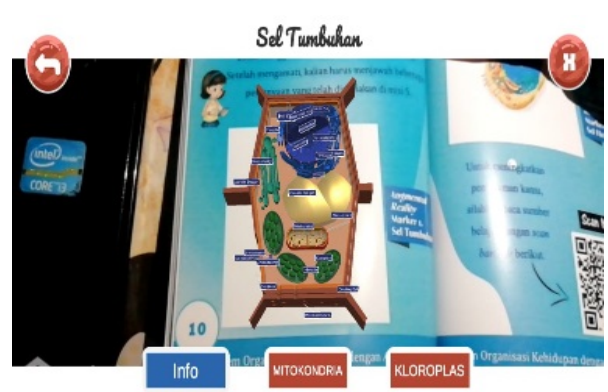

(c)

Figure 2. (a) Cover, (b) Collecting data mission on learning material (c) AR mission to collect plant's cell

\section{b. Product Validity}

Based on validation result, the average for both material expert and media validation were $84 \%$ with appropriate criteria. Truth test for life organization material was score of 1 in average with correct category which means the learning material was correct. Based on the validation test, it can be concluded that Augmented Reality-assisted guided inquiry learning model materials in the activity of identifying life organization system was valid and appropriate for the learning activity. 
The use of teaching materials by student is done by reading the instructions for using the books provided in the teaching materials, if student is in the classroom, they can read the instructions for using books and pay attention to the explanations from the teacher. On the other side, the use of learning material by teachers was carried out by understanding the manual and the content of the book with guided inquiry phases. Therefore, they could guided the student if they experienced difficulty during the learning process.

Android-based media learning and the use of learning model can improve the interest the students to learn, understand the abstract concepts and to construct knowledge independently. Junior High School/Islamic Junior High School students need interesting, interactive learning materials that can make them easier to study abstract concepts. Learning materials in a booklet will help students to use it in their own will. The use of media and learning model on a subject is a visual learning solution during the Covid-19 pandemic era.

\section{Conclusion}

The learning material development produced Augmented Reality-assisted guided inquiry learning model materials in the activity of identifying life organization system for 7 th-graders in Junior High School/Islamic Junior High School. The average validation percentage of more than $81 \%$. Based on those results, the learning material was valid and appropriate to use in the learning activity in both schools and home during the Covid-19 era..

\section{References}

[1] Aji S, Hudha MN, Rismawati A. Pengembangan Modul Pembelajaran Fisika Berbasis Problem Based Learning untuk Meningkatkan Kemampuan Pemecahan Masalah Fisika. SEJ (Science Educ Journal). 2017;1(1):36-51.

[2] Rizal. Pengaruh pembelajaran inkuiri terbimbing dengan mind map terhadap keterampilan proses sains dan hasil belajar IPA. J Pendidik sains [Internet]. 2014;2(4):159-65. Tersedia pada: http://journal.um.ac.id/index.php/jps

[3] Arviansyah R, Indrawati I, Harijanto A. Pengaruh Model Pembelajaran Guided Inquiry Disertai Lks Audiovisual Terhadap Aktivitas Dan Hasil Belajar Ipa Siswa Di Smp. J Pembelajaran Fis. 2016;4(4):308-314-314.

[4] Schleicher A. PISA 2018 insights and interpretations. OECD Publ [Internet]. 2019;64. Tersedia pada: https://www.oecd.org/pisa/PISA 2018 Insights and Interpretations FINAL PDF.pdf 
[5] Kolin FAM, Priyayi DF, Hastuti SP. Pengembangan Modul Berbasis Keterampilan Proses Sains (KPS) pada Materi Sistem Organisasi Kehidupan Tingkat Sel. BIOEDUSAINS J Pendidik Biol dan Sains. 2018;1(2):163-76.

[6] Masrur H, Corebima AD, Ghofur A. Pengembangan Buku Suplemen Mutasi Gen Pada Matakuliah Genetika. J Pendidik. 2017;2(9):1160-7.

[7] Ni'mah S. Lembar Kerja Mahasiswa Berbasis Inkuiri Terbimbing Untuk Meningkatkan Keterampilan Proses Sains Mahasiswa. J Ilm Kependidikan. 2016;11(2):70-9.

[8] Latifah S, Utami A. PENGEMBANGAN BAHAN AJAR INTERAKTIF BERBASIS MEDIA SOSIAL SCHOOLOGY DEVELOPMENT OF INTERACTIVE PHYSICS TEACHING IPTEK untuk bersaing dengan dunia global, Terlebih lagi peserta didik sudah terbiasa memanfaatkan internet dalam kehidupan sehari-hari . Pada p. 2019;02(1):36-45.

[9] Masykur R, Nofrizal, Syazali M. Pengembangan Media Pembelajaran Matematika dengan Macromedia Flash. J Pendidik Mat. 2017;8(2):177-86.

[10] Zamsuri A, Suandi F, Novendra R. Penerapan Augmented Reality Sebagai Media Pembelajaran Multimedia : Studi Kasus Videografi. J Intra Tech. 2019;3(2):54-9.

[11] Sun M, Wu X, Fan Z, Dong L. Augmented reality based educational design for children. Int J Emerg Technol Learn. 2019;14(3):51-60.

[12] Saputri, Fitriani Eka and Annisa, Muhsinah and Kusnandi D. Pengembangan Media Pembelajaran IPA Menggunakan Augmented Reality (Ar) Berbasis Android pada Siswa Kelas III SDN 015 Tarakan. Widyagogik. 2018;6. No.1:57-72.

[13] Mantasia M, Jaya H. Pengembangan Teknologi Augmented Reality Sebagai Penguatan Dan Penunjang Metode Pembelajaran Di Smk Untuk Implementasi Kurikulum 2013. J Pendidik Vokasi. 2016;6(3):281.

[14] Kristanto EK. Pengaruh Model Pembelajaran Inkuiri Terbimbing terhadap Kemampuan Berpikir Kritis dan Hasil Belajar IPA Siswa Kelas VII SMP. J Pendidik dan Pembelajaran Univ Negeri Malang. 2015;22(2):197-208.

[15] Ningrum WP, Arty IS. Penerapan Model Pembelajaran Berpusat Siswa Dalam Mengembangkan Keterampilan Proses Sains Dan Pemecahan Masalah Siswa. J Pendidik Kim. 2018;2(2):71-9.

[16] Yulita E. Pengembangan Modul Pembelajaran IPA Berbasisi Inkuiri Terbimbing Untuk Meningkatkan Keterampilan Proses Dasar Sains Peserta Didik Kelas IV MI/SD. J Madrasah Ibtidaiyah Educ. 2018;2(2):165-80. 
[17] Prihatin P, Prayitno BA, Rinanto Y. Pengembangan modul berbasis inkuiri terbimbing pada materi jamur untuk meningkatkan kemampuan berpikir kritis siswa kelas X SMA Negeri 1 Cepogo Boyolali. J Inkuiri. 2017;6(1):75-90.

[18] Permatasari I, Ramdani A, Syukur A. Pengembangan Bahan Ajar Ipa Berbasis Inkuiri Terintegrasi Sets (Science, Environment, Technology And Society) Pada Materi Sistem Reproduksi Manusia. J Pijar MIPA. 2019;1(1):1-13.

[19] Kemendikbud. Surat Edaran Nomor 4 Tahun 2020. 2020;300.

[20] Lee WW, Owens DL. Multimedia-Based Instructional Design. Pfeiffer. San Francisco; 2004.

[21] Likert R. A Technique for the Measurement of Attitudes. In: Encyclopedia of Research Design. 1932. hal. 5-55.

[22] Riduwan, Akdon. Rumus dan Data dalam Analisis Statiska. Kelima. Bandung: Cv. Alfabeta; 2013.

[23] Wahyuni R, Hikmawati H, Taufik M. Pengaruh Model Pembelajaran Inkuiri Terbimbing dengan Metode Eksperimen terhadap Hasil Belajar Fisika Siswa Kelas XI IPA SMAN 2 Mataram Tahun Pelajaran 2016/2017. J Pendidik Fis dan Teknol. 2017;2(4):165-9.

[24] Tsai CW. The applications of augmented reality for universal access in online education. Univers Access Inf Soc. 2019;18(2):217-9. 